\title{
KINETIC STUDIES ON SOLUBLE AND IMMOBILIZED ALPHA AMYLASE AND GLUCOAMYLASE
}

\author{
K. BALASUBRAMANIAM AND V.ASANTHY ARASARATNAM \\ Department of Biochemistry, Faculty of Medicine, University of Jaffna, Jaffna, Sri Lanka
}

(Date of receipt : 30 April 1986)

(Date of acceptance : 03 April 1989)

\begin{abstract}
Alpha amylase and glucoamylase were coupled seperately to Sepharose4B which was activated by an electrophilic method (by using cyanogen bromide). The kinetic properties of these enzymes in immobilized form were compared with those of their soluble enzymes. The $\mathrm{Km}$ values of soluble and immobilized alpha amylase for starch were $0.89 \%(\mathrm{~W} / \mathrm{V})$ and $1.33 \%(\mathrm{~W} / \mathrm{V})$ respectively at $\mathrm{pH} 6.9$ and at $40^{\circ} \mathrm{C}$ and the $\mathrm{Km}$ values of soluble and immobilized glucoamylase for starch were $0.25 \%(\mathrm{~W} / \mathrm{V})$ and $0.72 \%\left(\mathrm{~W} / \mathrm{V}\right.$ ) respectively at $\mathrm{pH} 4.8$ and at $50^{\circ} \mathrm{C}$. The optimum $\mathrm{pH}$ for soluble alpha amylase compared with that of the immobilized enzyme shifted from 6.9 to 6.5 in $0.02 \mathrm{M}$ phosphate buffer while in the case of glucoamylase the $\mathrm{pH}$ optimum in $0.01 \mathrm{M}$ acetate buffer increased from 4.8 to 5.2 on immobilization. There was no shift in optimum phosphate concentration $(0.02 \mathrm{M})$ for both soluble and immobilized alpha amylase at $\mathrm{pH}, 6.9$ and at $40^{\circ} \mathrm{C}$ and likewise no shift in optimum acetate concentration $(0.01 \mathrm{M})$ for soluble and immobilized glucoamylase at $\mathrm{pH}$ 4.8 and at $50^{\circ} \mathrm{C}$. The optimum temperature for the activities of soluble alpha amylase compared with the immobilized enzyme assayed in $0.02 \mathrm{M}$ phosphate buffer (pH 6.9) shifted from $45^{\circ} \mathrm{C}$ to $50^{\circ} \mathrm{C}$ and that of glucoamylase assayed in $0.01 \mathrm{M}$ acetate buffer ( $\mathrm{pH} 4.8$ ) shifted from $55^{\circ} \mathrm{C}$ ro $58^{\circ} \mathrm{C}$.
\end{abstract}

\section{Introduction}

Enzymes of industrial or analytical use could have increased applicability, if they could be immobilized while still in an active state: Many studies have been reported on the preparation of immobilized enzymes. ${ }^{2,3,6,7,8}$ Great interest in the use of water insoluble enzymes has been shown in industry. These enzymes can be readily recovered from the reaction mixture resulting in a considerable saving in process costs by repeatedly using the enzymes. ${ }^{9}$

Many products are currently produced from starch through the use of enzymes, whether soluble or immobilized. Both alpha amylase $(1,4-\alpha-D$ glucan glucanohydrolase; E.C.3.2.1.1) and glucoamylase $(1,4-\alpha-\mathrm{D}$ glucan glucohydrolase; E.C.3.2.1.3) are important industrial enzymes. These are used in large scale for liquefaction and saccharification of starch.

Immobilized enzymes may exhibit slightly altered chemical and physical properties. ${ }^{6,8}$ Therefore while designing chemical reactors for utilizing immobilized enzymes, certain parameters such as catalyst size, liquid flowrate, temperature, $\mathrm{pH}$, ionic strength, substrate concentration etc., must be carefully controlled in order to yield optimum conversion.

Our earlier study was undertaken to develop a functional immobilized alpha. amylase and glucoamylase. ${ }^{1}$. This paper compares the kinetic proper- 
ties of the soluble and immobilized forms of alpha amylase and glucoamylase. A knowledge of the kinetic parameters could be helpful in the design of reactors for continuous production of liquid glucose from soluble starch.

\section{Materials and Methods}

\subsection{Materials}

Alpha amylase (Hog pancreas) was obtained from Sigma Chemical Company, U.S.A. crude glucoamylase (Aspergillus niger) was from Ceylon Institute of Scientific and Industrial Research (C.I.S.I.R.), Sri Lanka, Sepharose-4B was from Pharmacia Fine Chemicals, and starch (soluble) was from BDH, UK. Cyanogen bromide was prepared in our laboratory. ${ }^{1}$

\subsection{Immobilization of Alpha Amylase and Glucoamylase to Sepharose - 4B}

In the preparation of both the immobilized alpha amylase and glucoamylase the soluble enzymes used had a specific activity of $906 \mathrm{u} / \mathrm{mg}$ protein and $370 \mathrm{u} / \mathrm{mg}$ protein respectively. They were prepared by electrophilic method. ${ }^{1}$

In the comparative studies equal amounts of soluble and immobilized enzyme proteins $(0.96 \mathrm{mg}$ protein as determined by micro-Kjeldhal method) were used.

The reducing equivalents produced by the action of alpha amylase and glucoamylase on starch were mieasured in terms of maltose and glucose respectively. ${ }^{4}$

One unit of alpha amylase will liberate $1 \mu \mathrm{g}$ of maltose from starch in 3 $\min$ at $\mathrm{pH} 6.9$ and at $40^{\circ} \mathrm{C}$. One unit of glucoamylase will liberate $1 \mu \mathrm{g}$ of glucose from starch in $10 \mathrm{~min}$ at $\mathrm{pH} 4.8$ and at $50^{\circ} \mathrm{C}$.

\subsection{Kinetic Properties of Soluble and Immobilized Alpha Amylase and Glucoamylase}

The Michaelis constants $(\mathrm{Km})$ of both soluble and immobilized alpha amylase and glucoamylase were estimated by varying the concentrations of starch from $0.1 \%$ (W/V.) to $2.0 \%(\mathrm{~W} / \mathrm{V})$ in $0.02 \mathrm{M}$ phosphate buffer ( $\mathrm{pH} 6.9$ ) at $40^{\circ} \mathrm{C}$ and in $0.01 \mathrm{M}$ acetate buffer $(\mathrm{pH} 4.8)$ at $50^{\circ} \mathrm{C}$ respectively.

The effect of $\mathrm{pH}$ on the activities of alpha amylase and glucoamylase was studied by altering the $\mathrm{pH}$ from 5.6 to 8.0 of $0.02 \mathrm{M}$ phosphate buffer at $40^{\circ} \mathrm{C}$ and from 3.6 to 6.0 of $0.01 \mathrm{M}$ acetate buffer at $50^{\circ} \mathrm{C}$ respectively.

Phosphate buffer $(\mathrm{pH}$ 6.9) in the range of 0.01 to $0.12 \mathrm{M}$ for a alpha amylase at $40^{\circ} \mathrm{C}$ and acetate buffer $(\mathrm{pH} 4.8)$ in the range of 0.004 to $0.05 \mathrm{M}$ for glucoamylase at $50^{\circ} \mathrm{C}$ were used to study the effect of ionic strengths on these enzymes. 
The temperature optimum for alpha amylase in $0.02 \mathrm{M}$ phosphate buffer $(\mathrm{pH} 6.9)$ and glucoamylase in $0.01 \mathrm{M}$ acetate buffer $(\mathrm{pH} 4.8)$ were studied in the range of $4^{\circ} \mathrm{C}$ to $80^{\circ} \mathrm{C}$.

The percentage activity was calculated in all cases (Figures $1 \& 2$; Table I, II \& III) for both alpha amylase and glucoamylase as the activity at a particular condition / the maximum activity obtained in that set of experimental conditions $\mathrm{x} 100$.

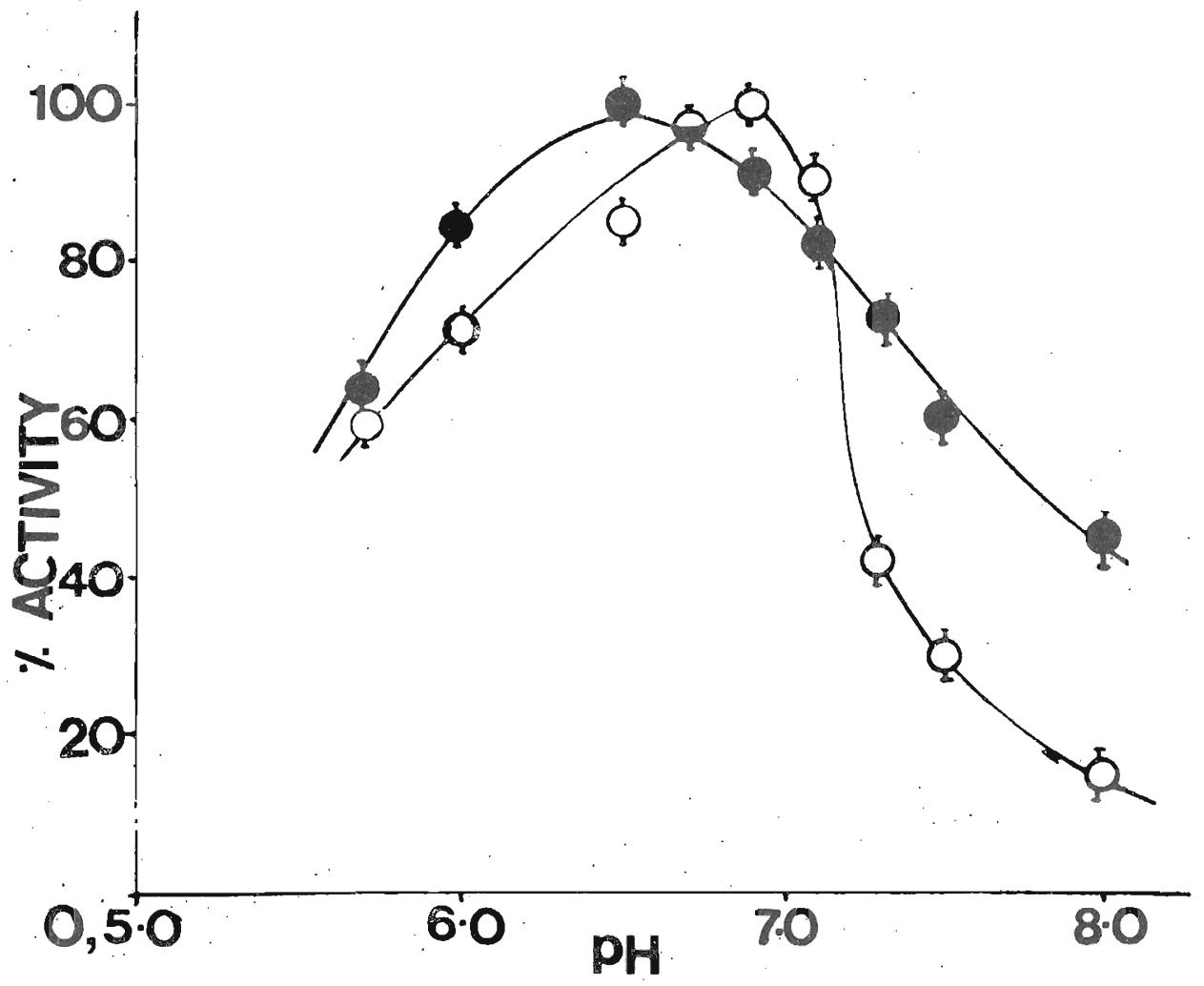

Figure 1. Effect of $\mathrm{pH}$ on soluble and imrnobilized alpha amylase activity in $0.02 \mathrm{M}$ phosphate buffer at $40^{\circ} \mathrm{C}$.

- O-Soluble enzyme

- - Immobilized enzyme.

(Each point is the mean of 4 experiments carried out in duplicates and bars indicate the standard deviations). 


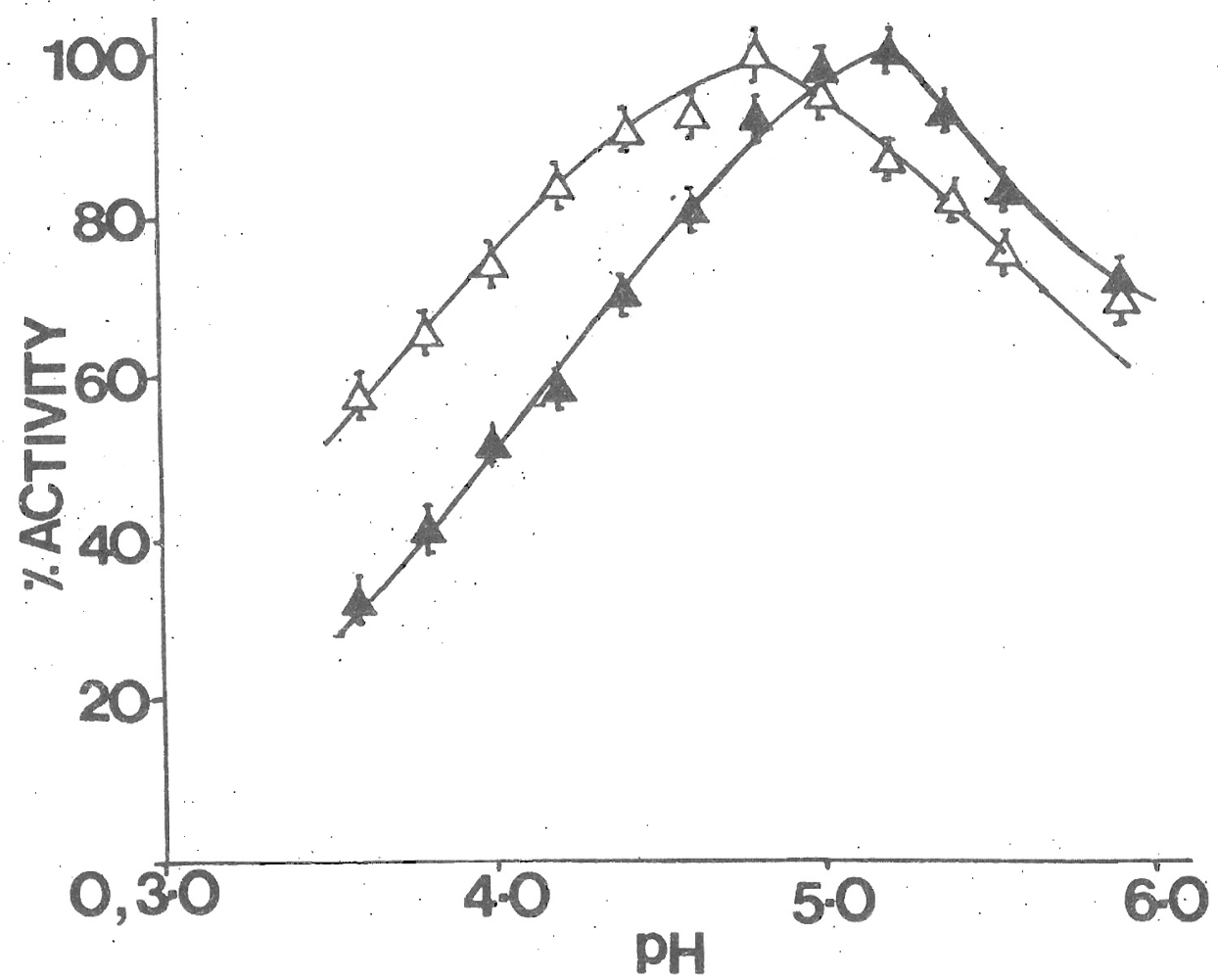

Fighre 2. Effect of $\mathrm{pH}$ on soluble and immobilized glucoamylase activity in $0.01 \mathrm{M}$ acetate buffer at $50^{\circ} \mathrm{C}$.

$\Delta-\Delta-$ Soluble enzyme

A-Immobilized enzymes.

(Each point is the mean of 4 experimenis carried out in duplicates and bars indicate the standard deviations).

\section{Results and Discussion}

The $\mathrm{Km}$ values of soluble and immobilized alpha amylase for starch. (calculated from Lineweaver - Burk plots) were $0.89 \%$ and $1.33 \%$ respectively and that of soluble and immobilized glucoamylase for starch were $0.25 \%$ and $0.72 \%$ respectively. Krakowick et. al. ${ }^{6}$ have immobilized glúcoamylase (type 150, Novo) on aluminium oxide and on áluminium oxide activated by $\mathrm{TiCl}_{4}$. The $\mathrm{Km}$ values of soluble glucoamylase, glucoamylase immobilized to aluminium oxide and glucoamylase coupled to activated aluminium oxide for starch were found to be $0.5 \%, 6.69 \%$ and $28.15 \%$ respectively. The increase in $\mathrm{Km}$ value of immobilized enzymes to that of the soluble enzyme may be due to the limitations of diffusion caused by unstirred layer which 
surrounds the water insoluble particles. This causes a decrease in the affinity or an increase in the $\mathrm{Km}$ of the enzyme for the substrate.

The optimum $\mathrm{pH}$ values for soluble and immobilized alpha amylase were 6.9 and $\hat{0} .5$ in $0.02 \mathrm{M}$ phosphate buffer (Figure 1) and for soluble and immobilized glucoamylase were 4.8 and 5.2 in $0.01 \mathrm{M}$ acetate buffer (Figure 2). Purified glucoamylase from Aspergillus niger showed the $\mathrm{pH}$ optimum at 4.3 with relatively high activity in the $\mathrm{pH}$ range between 3.6 and $4.6 .^{5}$ But in our experiment the crude enzyme used showed a $\mathrm{pH}$ optimum of 4.8 which could be due to the presence of isoenzymes. Wykes et. al. ${ }^{8}$ showed that the optimum $\mathrm{pH}$ values for soluble and $\mathrm{CM}$ - cellulose bound alpha amylase were 6.0 and 6.5 respectively. In that study $\mathrm{CM}$-cellulose which has a negatively charged matrix was used while in this study the matrix (sepharose-4B) was neutral and hence, the change in $\mathrm{pH}$ optimum could not be due to the charge effect of the matrix. It is possibly due to the changes in conformation of the enzymes resulting from immobilization.

The concentration of phosphate buffer had a marked effect on soluble alpha amylase compared to the immobilized enzyme (Table 1 ). Although the soluble and the immobilized alpha amylase showed optimal activity at $0.02 \mathrm{M}$ phosphate concentration, the immobilized alpha amylase had considerably higher activities than the soluble alpha amylase at all other phosphate concentrations. Likewise the immobilized glucoamylese at all acetate concentrations except at the optimal $0.01 \mathrm{~N}$ acetate concentration (Table 2).

Table 1. Effect of phosphate concentration on soluble and immobilized alpha amylase activities at $\mathrm{pH} 6.9$ and at $40^{\circ} \mathrm{C}$.

\begin{tabular}{crr}
\hline $\begin{array}{l}\text { Concentration of } \\
\text { phosphate }(\mathrm{mM})\end{array}$ & \multicolumn{1}{c}{$\%$ Activity of alpha amylase } \\
\hline 10 & 56 & Soluble \\
20 & 100 & 100 \\
30 & 60 & 95 \\
40 & 45 & 90 \\
50 & 36 & 75 \\
70 & 31 & 67 \\
100 & 25 & 64 \\
120 & 24 & 61 \\
\hline
\end{tabular}

Mean value of 3 experiments as described in section 2.3 .

Absolute activities for soluble and immobilized alpha amylase were $870 \mathrm{u} / \mathrm{ml}$ and $1430 \mathrm{u} / \mathrm{ml}$ respectively. 
Table 2. Effect of acetate concentration on soluble and immobilized glucoamylase activities at $\mathrm{pH} 4.8$ and at $50^{\circ} \mathrm{C}$.

\begin{tabular}{|c|c|c|}
\hline \multirow{2}{*}{$\begin{array}{l}\text { Concentration of } \\
\text { acetate }(\mathrm{mM})\end{array}$} & \multicolumn{2}{|c|}{ : Activity of glucoamylase } \\
\hline & Soluble & Immobilized \\
\hline 4 & 77 & 90 \\
\hline 6 & 90 & 96 \\
\hline 8. & 99 & 98 \\
\hline 10 & 100 & 100 \\
\hline 20 & 90 & $s 7$ \\
\hline 30 & 81 & 94 \\
\hline 40 & 74 . & 87. \\
\hline 50 & 66 & 83 \\
\hline
\end{tabular}

Mean values of 3 experiments as described in section 2.3 .

Absolute activities of soluble and immobilized glucoamylase were $355 \mathrm{u} / \mathrm{ml}$ and $390 \mathrm{u} / \mathrm{ml}$ respectively.

The optimum temperature for soluble and immobilized alpha amylase were $45^{\circ} \mathrm{C}$ and $50^{\circ} \mathrm{C}$ respectively and that of soluble and immobilized glucoamylase were $55^{\circ} \mathrm{C}$ and $58^{\circ} \mathrm{C}$ (Table 3 ) showing that immobilization had increased the optimum temperature of both enzymes slightly. 
Table 3. Effect of temperature on the activities of soluble and immobilized alpha amylase (in $0.02 \mathrm{M}$ phosphate buffer $\mathrm{pH} \mathrm{6.9)}$ ) and glucoamylase (in $0.01 \mathrm{M}$ acetate buffer $\mathrm{pH} 4.8$ ).

\begin{tabular}{|c|c|c|c|c|}
\hline \multirow{3}{*}{$\begin{array}{l}\text { Temperature } \\
\left({ }^{0} \mathrm{C}\right)\end{array}$} & \multicolumn{4}{|c|}{$\%$ Activity } \\
\hline & \multicolumn{2}{|c|}{ Alpha amylase } & \multicolumn{2}{|c|}{ Glucoamylase } \\
\hline & . Soluble & Immobilized & Soluble & Immobilized \\
\hline 04 & 36 & 29 & 23 & 52 \\
\hline 3.0 & 57 & 56 & 43 & 61 \\
\hline 40 & 87 & 78 & 55 & 68 \\
\hline 45 & 100 & 87 & 70 & 75 \\
\hline 50 & 79 & 100 & 80 & 83 \\
\hline 55 & 55 & 77 & 100 & 95 \\
\hline 58 & - & - & 97 & 100 \\
\hline 50 & 35 & 56 & 95 & 97 \\
\hline 70 & 25 & 41 & 48 & 70 \\
\hline 80 & 20 & 26 & 14 & 50 \\
\hline
\end{tabular}

Mean values of 3 experiments as described in section 2.3 .

Absolute activities of soluble and immobilized alpha amylase were $1000 \mathrm{u} / \mathrm{mi}$ and $1833 \mathrm{u} / \mathrm{ml}$ respectively and that for glucoamylase were $444 \mathrm{u} / \mathrm{ml}$ and $470 \mathrm{u} / \mathrm{ml}$ respectively.

\section{References}

1. ARASARATNAM, v. \& BAlaSUBRAMANIAM, K. (1987) J. Natn. Sci Coun. Sri Lanka, $15(2): 217-226$

2. CALLDWELL, K. D. (1976) Inaugural dissertation, Bio Medical Center, Uppsala, Sweden.

3. GRAY, C. J., LIVINGSTONE, C. M., JONES, C. M. \& BÁRKER, S. A (1974) Biochem. Biopbys. Acta, 341; 457.

4. HOSTElter, H., BOREL, E. \& DEUEL, H. (1951) Helvetica chemica Acta, XXXIV. (6); 2132.

5. JANSZ, E. R., PIERIS, N., JEYARAJ, E. E. \& DE SIlVA, N. (1977) J. Natn. Sci Coun. Sri Lanka, $5 ; 59$.

6. KRAKOWIAK, W.; JACH, M., KORON/., J. \& SUGIER, H. (1984) Starch, 36 ; 396.

7. MOSBACK, K. (1971) Sci. Americain, $224 ; 26$.

8. WYKES, J. R., DUNILL, P. \& LILLY, M.D. (1971) Biocbem. Biophys Acta, $250 ; 522$.

9. ZABORSKY, O. R. (1974) Immobilized Enzymes, O.R. Zaborsky ed. Chemical Rubber Co., Cleverland, Ohio. 